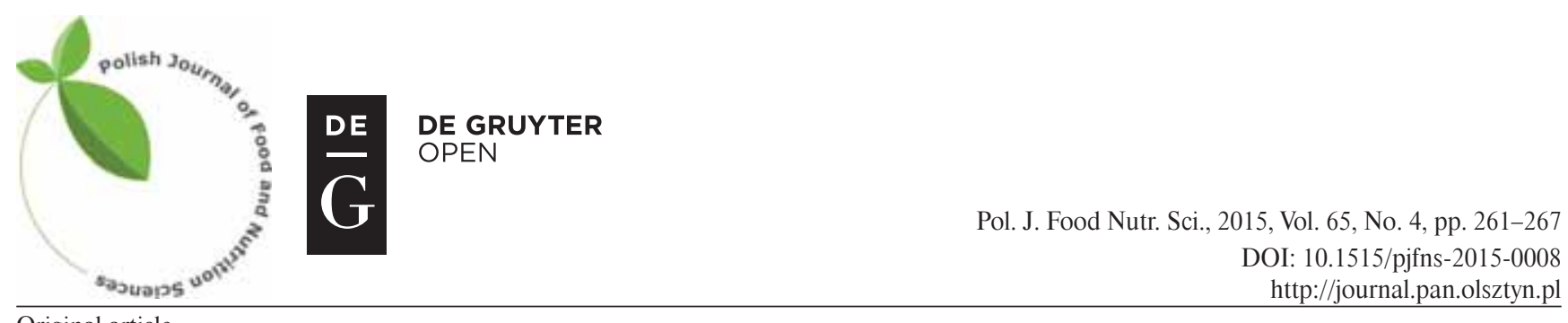

Original article

Section: Food Quality and Functionality

\title{
Microbiological and Sensory Quality of Milk on the Domestic Market
}

\author{
Anna Piotrowska*, Franciszek Świderski, Eliza Kostyra, Matgorzata Żebrowska-Krasuska, Anna Sadowska \\ Department of Organic and Functional Food and Commodities, Faculty of Human Nutrition and Consumer \\ Sciences, Warsaw University of Life Sciences, Nowoursynowska 159C, 02-776 Warsaw, Poland
}

Key words: milk, microbiological quality, sensory quality

The evaluation of the microbiological and sensory quality of 30 assortments of market milk was the objective of the presented research. The study also compared the sensory profile of selected samples of milk differing in preservation method. Microbiological tests included determination of the presence and number of Enterobacteriaceae and the total number of microorganisms. Sensory characteristics of all the milk samples was performed by scaling method (5-points scale). Selected samples of milk were additionally assessed by means of profile method. Microbiological tests showed satisfactory microbiological purity of milk, which indicates the effectiveness of the heat treatment and the lack of secondary contamination. Regardless of the preservation method, all the evaluated milk samples were characterised by a high sensory quality ( $4.25-5$ points). There were no changes in smell and taste, resulting from the development of undesirable microflora. The tested samples of milk differing in the preservation method (sterilisation, pasteurisation at high temperature and subjected to microfiltration and low pasteurisation) varied in the sensory profile. Milk pasteurised at high temperature was characterised by the most harmonised overall quality.

\section{INTRODUCTION}

Milk is a product that plays an important role in a human diet, owing to high nutrient density and high concentration of the majority of nutrients in relation to the amount of supplied energy [Zmarlicki, 2009; Ebringer et al., 2008]. However, at the same time, milk is an excellent substrate for microorganisms. The development of unwanted microflora reduces the nutritional value of the product, adversely affects the sensory quality by contributing changes in taste, aroma and texture. The presence of pathogenic microflora is particularly detrimental from the human health point of view [Gandy et al., 2008; Hettinga et al., 2008; Hayes et al., 2002].

In order to ensure the safety of this product pasteurisation or sterilisation of milk are used as the main preservation methods. Due to the long shelf-life and ease of storage, UHT milk is very popular with consumers. However, the sterilisation process contributes to the loss of valuable, from the nutritional point of view, labile milk components, it has a negative impact on sensory properties of milk as well [Sakkas et al., 2014; Rysstad \& Kolstad, 2006]. An increasingly wider group of consumers expects milk to be similar in taste to pasteurised milk but with a longer shelf life. The need for extending the shelf life of pasteurised milk, without the negative flavour change normally associated with UHT, resulted in development of ESL (Extended Shelf Life) milk. Various combina-

\footnotetext{
* Corresponding Author: E-mail: anna_piotrowska@sggw.pl (A. Piotrowska)
}

tions of preservation processes can be used in the production of ESL milk. The physical methods (e.g. microfiltration) are most frequently used to remove bacterial cells and spores before pasteurisation. A low number of microorganisms in the milk after microfiltration allows using the milder temperature and time conditions in heat preservation process to destroy any remaining microflora with keeping better nutritional value and sensory quality of milk [Sakkas et al., 2014; Świderski, 2010; Rysstad \& Kolstad, 2006].

High microbiological quality of consumed milk is determined by good hygiene practices at each stage of its production. An important role is played by the technical equipment of households and buying raw material organisation, which determine the microbiological quality of raw milk entering the dairy plant. The standard of hygiene and service facilities in the plant, temperature and thermal processing conditions are important, as well as protection against secondary contamination of the product after the heat process [Smigic et al., 2012]. In the case of pasteurised and ESL milk, it is also important to ensure the proper transport conditions and storage temperature of the finished product. According to the literature, for every $2-3^{\circ} \mathrm{C}$ increase in storage temperature, the shelf life of pasteurised milk is reduced by half [Gandy et al., 2008; Rysstad \& Kolstad, 2006]. Meanwhile experimental data have shown that in more than a half of the places where the milk is stored (refrigerated counters in commercial domestic refrigerators), the temperature exceeded the recommended level, the differences reached even $14^{\circ} \mathrm{C}$ [Jakubczyk \& Bogdańska-Zaręba, 2009]. Rysstad \& Kolstad found that as soon as pasteurised milk left the dairy plant, its tempera- 
TABLE 1. Microbiological quality of milk - the presence and number of Enterobacteriaceae and total bacteria count at $30^{\circ} \mathrm{C}$.

\begin{tabular}{l|c|c}
\hline \multirow{2}{*}{ Samples } & \begin{tabular}{c} 
Total bacteria count \\
\cline { 2 - 3 }
\end{tabular} & $\begin{array}{c}\text { Presence and number } \\
\text { of Enterobacteriaceae }\end{array}$ \\
\hline \multicolumn{3}{|c}{ UHT milk containing 3.2\% of fat } \\
\hline p1 UHT & & \\
p2 UHT & & \\
p3 UHT & & \\
p4 UHT & below 1 CFU $/ \mathrm{mL}$ \\
p5 UHT & & \\
p6 UHT & below 1 CFU $/ \mathrm{mL}$ & \\
p7 UHT & & \\
p8 UHT & & \\
\hline
\end{tabular}

\begin{tabular}{lc}
\hline & UHT milk containing $2 \%$ of fat \\
\hline p9 UHT & \\
p10 UHT & below $1 \mathrm{CFU} / \mathrm{mL} \quad$ below $1 \mathrm{CFU} / \mathrm{mL}$ \\
p11 UHT & \\
p12 UHT & \\
\hline
\end{tabular}

UHT milk containing $1.5 \%$ of fat

p13 UHT
p14 UHT
p15 UHT
p16 UHT

\begin{tabular}{lcr}
\hline & UHT milk containing $0.5 \%$ of fat \\
\hline p17 UHT & & \\
p18 UHT & below $1 \mathrm{CFU} / \mathrm{mL}$ & below $1 \mathrm{CFU} / \mathrm{mL}$ \\
p19 UHT & & \\
p20 UHT & &
\end{tabular}

\begin{tabular}{|c|c|c|}
\hline \multicolumn{3}{|c|}{ Milk containing $3.2 \%$ of fat pasteurised at high temperature } \\
\hline p1 HP & below $1 \mathrm{CFU} / \mathrm{mL}$ & below $1 \mathrm{CFU} / \mathrm{mL}$ \\
\hline \multicolumn{3}{|c|}{ Milk containing $2 \%$ of fat pasteurised at high temperature } \\
\hline \multicolumn{3}{|l|}{ p2 HP } \\
\hline \multicolumn{3}{|l|}{ p3 HP } \\
\hline p4 HP & below $1 \mathrm{CFU} / \mathrm{mL}$ & below $1 \mathrm{CFU} / \mathrm{mL}$ \\
\hline \multicolumn{3}{|l|}{ p5 HP } \\
\hline p6 HP & & \\
\hline
\end{tabular}

\begin{tabular}{|c|c|c|}
\hline \multicolumn{3}{|c|}{$\begin{array}{l}\text { Milk containing } 3.2 \% \text { of fat subjected to } \\
\text { microfiltration and low pasteurisation }\end{array}$} \\
\hline $\begin{array}{l}\text { p1 MFLP } \\
\text { MFLTLP }\end{array}$ & $\begin{array}{l}2.9 \times 10^{2} \mathrm{CFU} / \mathrm{mL} \\
{\left[2.5 \times 10^{2} ; 3.3 \times 10^{2}\right]}\end{array}$ & below $1 \mathrm{CFU} / \mathrm{mL}$ \\
\hline p2 MFLP & $\begin{array}{l}6.8 \times 10 \mathrm{CFU} / \mathrm{mL} \\
{[5.9 \times 10 ; 7.8 \times 10]}\end{array}$ & below $1 \mathrm{CFU} / \mathrm{mL}$ \\
\hline \multicolumn{3}{|c|}{$\begin{array}{l}\text { Milk containing } 3.2 \% \text { of fat subjected to } \\
\text { microfiltration and low pasteurisation }\end{array}$} \\
\hline p3 MFLP & $\begin{array}{l}3.0 \times 10^{4} \mathrm{CFU} / \mathrm{mL} \\
{\left[2.6 \times 10^{4} ; 3.5 \times 10^{4}\right]}\end{array}$ & below $1 \mathrm{CFU} / \mathrm{mL}$ \\
\hline p4 MFLP & $\begin{array}{l}6.8 \times 10^{2} \mathrm{CFU} / \mathrm{mL} \\
{\left[5.9 \times 10^{2} ; 7.8 \times 10^{2}\right]}\end{array}$ & below $1 \mathrm{CFU} / \mathrm{mL}$ \\
\hline
\end{tabular}

Explanatory notes: UHT - sterilised milk; HP - milk pasteurised at high temperature; MFLP - milk subjected to microfiltration and low pasteurisation. ture increased during transport to the retail store. In the supermarket, during the day, when doors to the chiller cabinets were frequently opened, the temperature exceeded $10^{\circ} \mathrm{C}$ [Rysstad \& Kolstad, 2006].

In view of the diversity of factors influencing the quality of the milk, control processes are of the almost importance to ensure its microbiological purity, that determines safety, high nutritional value and proper sensory quality. They should be carried out at every stage - applied to raw milk entering the dairies, milk leaving the processing plant and to the products on the market.

The aim of the study was to assess the microbiological purity and sensory quality of selected assortments of market milk. The paper also compares sensory profiles of milk differing in the preservation method.

\section{MATERIAL AND METHODS}

The study material consisted of 30 assortments of market milk including 4 subjected to microfiltration and low pasteurisation, 6 pasteurised at high temperature and 20 preserved by UHT method. Until the evaluation, samples were stored in conditions consistent with manufacturers' instructions. Microbiological and sensory quality assessment was carried out at the end of shelf life. Selected milk samples were also subjected to sensory evaluation directly after delivery to the laboratory using the profiling method.

The studied milk samples were determined for: total bacteria count (TBC) at $30^{\circ} \mathrm{C}$ according to Polish Standard PN-EN ISO 4833:2004 + Ap 1:2005, and the presence and number of Enterobacteriaceae according to Polish Standard PN-ISO 21528-2:2005.

The sensory evaluation was performed by the scaling method using a 5-point scale for quality attributes: appearance, odour, consistency and taste. The study was performed according to IDF Standard 99 C:1997, part. 1 and part. 3. The evaluation of samples attributes was performed according to the Commission Regulation (EC) No 273/2008 of 5 March 2008 stating down detailed rules for the application of the Council Regulation (EC) No 1255/1999 with reference to methods for the analysis and quality evaluation of milk and milk products. Each sample was analysed by a 9-person panel; the basis of the average results was 9 unit ratings.

Quantitative Descriptive Analysis method (QDA) was used to determine the detailed sensory characteristics of 6 selected market milk samples with the same fat content, differing in the preservation method. The study was conducted on the basis of 18 well-defined attributes, using the analytical procedure described in the Polish Standard PN-EN ISO 13299:2010. Each sample was analysed in two independent replications, the base of the average results was 20 individual ratings (10 panellists $\mathrm{x} 2$ sessions).

The sensory characteristics of the samples was performed by a trained and experienced panel qualified as experts according to the Polish Standard PN-EN ISO 8586:2014-03. The assessments were performed at the Laboratory of Sensory Analysis at the Faculty of Human Nutrition and Consumer Sciences, Warsaw University of Life Sciences, which met all the requirements specified in the standard PN-EN 
ISO 8589:2010. The computerised support system for sensory analysis ANALSENS NT was used for planning session ratings by the QDA method, generating random numbers for coding samples, recording individual results and their preliminary processing.

Individual milk samples in the amount of $\sim 30 \mathrm{~mL}$ were placed in the previously prepared and encoded plastic beakers $(100 \mathrm{~mL})$ and covered with lids. Non-carbonated mineral water was used as a taste neutraliser between samples. Sets of samples for the individual panellists were coded individually and presented in random order. Prior to sensory evaluation, the samples had been conditioned to room temperature in order to balance the aroma in the samples headspace.

The significance of differences in attributes intensity among milk samples assessed by the QDA method was verified using multivariate analysis of variance ANOVA and the criterion of the least significant difference NIR $(\mathrm{p} \leq 0.05)$. Principal Component Analysis was applied for the assessment of similarities and differences of sensory profiling characteristics in the evaluated samples.

\section{RESULTS AND DISCUSSION}

The results of microbiological tests (Table 1) indicate that Enterobacteriaceae was not found in any of evaluated milk samples $(<1 \mathrm{CFU} / \mathrm{mL})$, which proves the high hygienic quality of the tested milk and the effectiveness of the heat process. In accordance with Commission Regulation (EC) No 2073 /2005 of 15 November 2005 on microbiological criteria for foodstuffs (OJ L 338, 22.12.2005, as amended), the control of Enterobacteriaceae in pasteurised milk samples is obligatory and the contents should not exceed $10 \mathrm{CFU} / \mathrm{mL}$. Enterobacteriaceae bacteria are considered as indicators of hygienic quality of food products. Determination of their level enables the assessment of the correctness of procedures and hygiene throughout the production process, including the assessment of the effectiveness of the pasteurisation process. Pasteurisation destroys the Enterobacteriaceae bacteria, thus their presence indicates non-compliance with the required parameters of the heat treatment process or the secondary contamination after the heat treatment. Studies show that the presence of Enterobacteriaceae in excess of allowable limits is usually also accompanied by a significant number of other undesirable microorganisms and consequently sensory quality of products is reduced [Molska, 2007; Tortorello, 2003].

In all UHT and pasteurised at high temperature milk samples, the total bacteria count was lower than $1 \mathrm{CFU} / \mathrm{mL}$. In the group of microfiltered and pasteurised at low temperature milk, the TBC ranged from $6.8 \times 10 \mathrm{CFU} / \mathrm{mL}$ to $3.0 \times$ $10^{4} \mathrm{CFU} / \mathrm{mL}$.

In a study conducted by Molska \& Pałubińska [2006], concerning the microbiological quality of high-pasteurised market milk samples it was found that the tested milk has retained the microbiological quality throughout the storage period. Development of the microflora was observed during milk storage, but the total bacteria count did not exceed $10^{5} \times \mathrm{CFU}$ in $1 \mathrm{~mL}$ in any sample [Molska \& Pałubińska, 2006]. In this study, the TBC in high-pasteurised milk at the end of shelf life was very low (below $1 \mathrm{CFU}$ in $1 \mathrm{~mL}$ ), which proves high
TABLE 2. Sensory evaluation of milk by scaling method using a 5-point scale (mean scores $\mathrm{n}=9$ ).

\begin{tabular}{|c|c|c|c|c|}
\hline Samples & Appearance & Odour & Consistency & Taste \\
\hline \multicolumn{5}{|c|}{ UHT milk containing $3.2 \%$ of fat } \\
\hline p1 UHT & 4.90 & 4.55 & 4.90 & 4.50 \\
\hline p2 UHT & 4.50 & 4.35 & 5.00 & 4.75 \\
\hline p3 UHT & 4.80 & 4.45 & 4.80 & 4.55 \\
\hline p4 UHT & 4.95 & 4.25 & 4.90 & 4.45 \\
\hline p5 UHT & 5.00 & 4.65 & 5.00 & 4.80 \\
\hline p6 UHT & 4.90 & 4.70 & 4.95 & 4.75 \\
\hline p7 UHT & 4.90 & 4.25 & 4.90 & 4.55 \\
\hline p8 UHT & 4.90 & 4.70 & 4.95 & 4.55 \\
\hline \multicolumn{5}{|c|}{ UHT milk containing $2 \%$ of fat } \\
\hline p9 UHT & 4.55 & 4.75 & 5.00 & 4.95 \\
\hline p10 UHT & 5.00 & 4.70 & 5.00 & 4.75 \\
\hline p11 UHT & 5.00 & 4.70 & 5.00 & 4.80 \\
\hline p12 UHT & 5.00 & 4.70 & 5.00 & 4.75 \\
\hline \multicolumn{5}{|c|}{ UHT milk containing $1.5 \%$ of fat } \\
\hline p13 UHT & 5.00 & 4.90 & 5.00 & 4.95 \\
\hline p14 UHT & 5.00 & 4.95 & 5.00 & 4.85 \\
\hline p15 UHT & 5.00 & 4.40 & 5.00 & 4.50 \\
\hline p16 UHT & 5.00 & 4.89 & 5.00 & 4.78 \\
\hline \multicolumn{5}{|c|}{ UHT milk containing $0.5 \%$ of fat } \\
\hline p17 UHT & 4.94 & 4.78 & 5.00 & 4.61 \\
\hline p18 UHT & 5.00 & 4.61 & 5.00 & 4.39 \\
\hline p19 UHT & 5.00 & 5.00 & 5.00 & 4.89 \\
\hline p20 UHT & 5.00 & 4.81 & 4.94 & 4.25 \\
\hline
\end{tabular}

Milk containing $3.2 \%$ of fat pasteurised at high temperature

\begin{tabular}{|c|c|c|c|c|}
\hline p1 HP & 4.88 & 4.75 & 4.88 & 4.75 \\
\hline \multicolumn{5}{|c|}{ Milk containing $2 \%$ of fat pasteurised at high temperature } \\
\hline p2 HP & 5.00 & 4.75 & 4.88 & 4.63 \\
\hline p3 HP & 5.00 & 4.75 & 5.00 & 4.81 \\
\hline p4 HP & 4.86 & 4.64 & 4.86 & 4.57 \\
\hline p5 HP & 5.00 & 4.93 & 5.00 & 4.86 \\
\hline p6 HP & 5.00 & 4.94 & 5.00 & 4.81 \\
\hline \multicolumn{5}{|c|}{$\begin{array}{l}\text { Milk containing } 3.2 \% \text { of fat subjected to } \\
\text { microfiltration and low pasteurisation }\end{array}$} \\
\hline pl MFLP & 5.00 & 5.00 & 5.00 & 4.56 \\
\hline p2 MFLP & 5.00 & 4.94 & 5.00 & 4.81 \\
\hline \multicolumn{5}{|c|}{$\begin{array}{l}\text { Milk containing } 2 \% \text { of fat subjected to } \\
\text { microfiltration and low pasteurisation }\end{array}$} \\
\hline p3 MFLP & 5.00 & 4.69 & 4.86 & 4.44 \\
\hline p4 MFLP & 5.00 & 4.88 & 4.88 & 4.56 \\
\hline
\end{tabular}

Explanatory notes: UHT - sterilised milk; HP - milk pasteurised at high temperature; MFLP - milk subjected to microfiltration and low pasteurisation.

quality of raw milk, effectiveness of the pasteurisation process and lack of secondary contamination.

The evaluation of the sensory quality performed within this study showed no change in appearance, consistency, odour and taste as a result of the lack of undesirable micro- 
flora development. Irrespective of the preservation method and fat content, the scores given for certain attributes were not lower than 4 (Table 2).

The samples were characterised by adequate appearance without quality defects. Their colour was evaluated as typical, white with a slightly cream shade and intensity with little difference among all analysed samples. Milk aroma was typical, sweet and creamy. Odours that negatively affect the sensory quality of products e.g. unclean, cowshed and sour, were not perceived. The consistency of the tested milk was also highly rated - all samples were perceived as fluid and smooth. As far as milk taste is concerned, milky note, accompanied by sweet and fatty taste dominated. Adverse flavours, characteristic for undesirable changes in quality, were not detected.

Sensory quality is an important indicator of the overall quality and health safety of milk. One of the factors that reduces the risk of food poisoning due to the presence of Bacillus cereus in milk is the fact that the intensive development of this microflora causes changes in the sensory characteristics, disqualifying the product for consumption [Jakubczyk, 2004]. Most of psychrotrophic bacteria produce heat-resistant extracellular enzymes, such as lipases and proteases, which remain in the milk even after the destruction of bacterial cells as a result of heat treatment, causing adverse effects. These enzymes, particularly proteases, are characterised by high heat resistance, they survive pasteurisation temperature and even partially sterilisation [Skrzypek et al., 2002; Valero et al., 2001].
Sensory quality of milk depends on many factors including microbiological and chemical contamination, artificial or natural light exposure, storage temperature as well as cows feed. The flavour of high-quality milk has been described as bland, pleasantly sweet and free of defects. Due to milk naturally mild flavour, the development of any off-flavours is particularly noticeable in the product. Microbiological contamination has a major influence on milk quality [Aires et al., 2009; Gandy et al., 2008; Hettinga et al., 2008; Fromm \& Boor, 2004]. The nature of adverse changes in milk quality can vary depending on the type of present microorganisms. Pseudomonas bacteria produce lipases and proteases that cause the development of defects in taste and smell described as fruity, bitter, dirty and spoiled. Ethyl esters of FFAs are most likely responsible for the fruity off-flavour associated with the Pseudomonas development [Hettinga et al., 2008; Hayes et al., 2002]. Species Bacillus circulans ferments lactose, which leads to milk acidity increase and as a result to the increase of sour taste. In turn, Bacillus cereus is the cause of bitter taste appearance and the formation of a loose curd [Aires et al., 2009; Jakubczyk \& Bogdańska-Zaręba, 2009]. One of the main enzymatic reactions causing quality deterioration in milk is lipolysis. The breakdown of triglycerides to free fatty acids can cause an off-flavour described as rancid, butyric or cheesy. Pseudomonas fluorescens has been identified as a major contributor to lipolytic spoilage. Although rancid off-flavours in milk are often associated with the growth of lipolytic microorganisms, they may also result from the presence of indigenous lipoprotein lipase [Hettinga et al., 2008; Fromm \&Boor,

\begin{tabular}{|c|c|c|c|c|c|}
\hline p3 MFLP & 围 $\mathrm{p} 4 \mathrm{MFLP}$ & p2 HP & $\boldsymbol{\nabla} \mathrm{p} 4 \mathrm{HP}$ & ( $\mathrm{p} 9 \mathrm{UHT}$ & ㅁ. $\mathrm{p} 10 \mathrm{UHT}$ \\
\hline
\end{tabular}

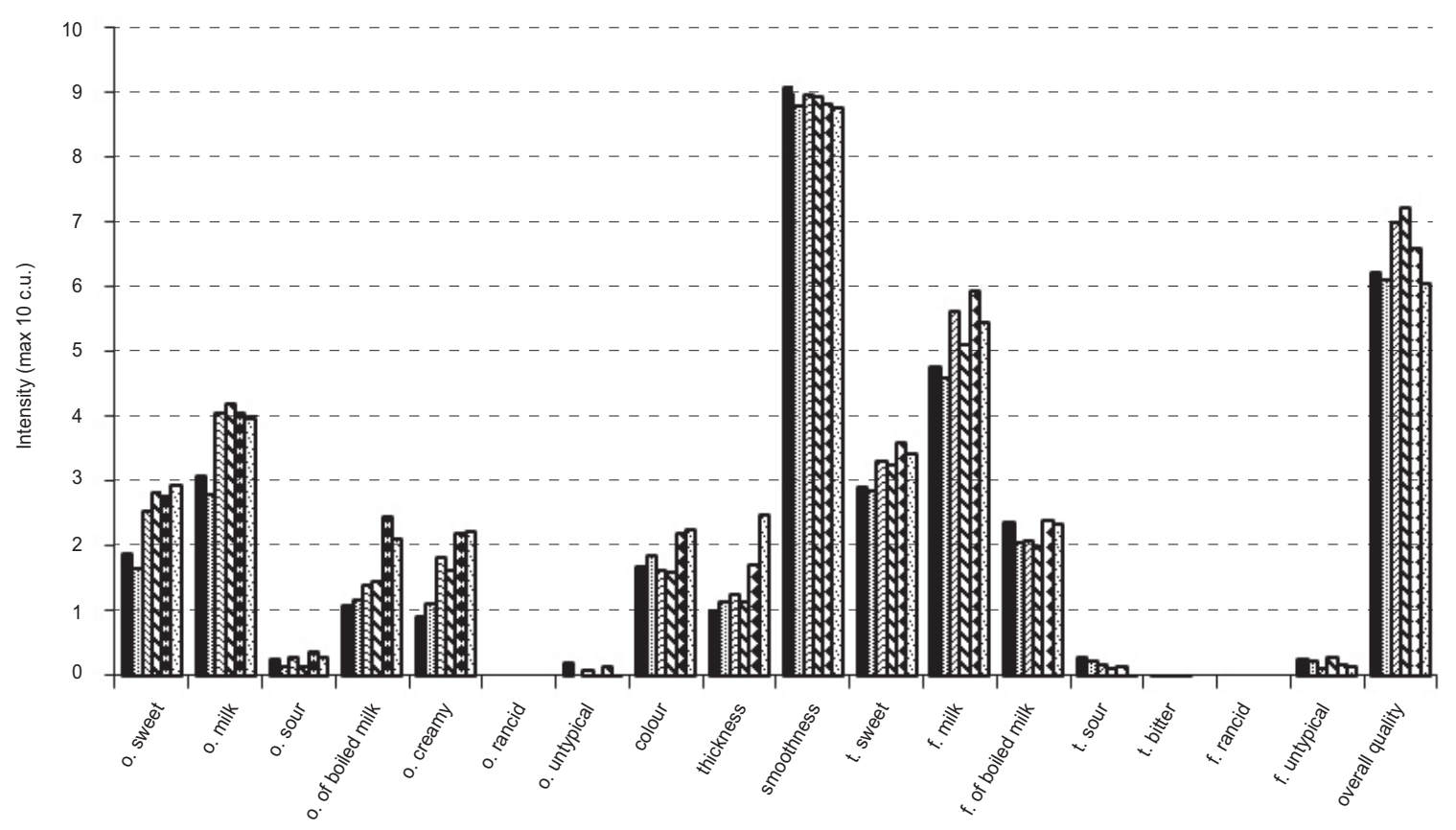

FIGURE 1. Sensory profile of market milk containing $2 \%$ of fat preserved with different methods.

Explanatory notes: UHT - sterilised milk; HP - milk pasteurised at high temperature; MFLP - milk subjected to microfiltration and low pasteurisation. Tested attributes: o. - odour, t. - taste / f. - flavor; o. sweet; o.milk; o. of boiled milk; o. creamy; o. rancid; o. untypical; colour; thickness; smoothness; t. sweet; f. milk; f. of boiled milk; t. sour; t. bitter; o. rancid; f. untypical; overall quality. 
2004; Hayes et al., 2002]. The activity of proteolytic enzymes of native or bacterial origin can lead to undesirable changes not only in flavour (bitterness particularly) but also in texture (the so-called gelatification as a result of the storage). It involves the gradual increase of the viscosity of the milk up to a full gelatinisation. These adverse effects result from a direct interaction between casein micelles and the formation of bonds of three-dimensional network [Dzwolak \& Ziajka, 1997]. According to the literature, an increased rate of proteolysis is observed in skimmed milk compared to whole milk [Valero et al., 2001]. Adverse changes in the sensory quality of milk can also result from the method of animal feeding. The presence of forage taste and odour may be associated with the use of poor quality forage silage typically with high $\mathrm{pH}$, a large amount of rapeseed meal, as well as frozen or stale forage [Jakubczyk \& Bogdańska-Zaręba, 2009]. Light is another factor that can affect sensory quality of milk. Both sunlight and artificial light have negative effects on milk quality and contribute to off-flavours development, described as light-activated, burnt or sunlight. The main reason for light-induced off-flavour is photo-oxidation of the amino acid methionine to the strong off-flavour compound - methional. Packaging can directly prevent the development of light-induced off-flavour by protecting the product from both light and oxygen. Transparent packaging materials, like glass or plastic, offer only minimal protection against harmful light [Gandy et al., 2008; Karatapanis et al., 2006; Rysstad \& Kolstad, 2006].

In studies of low pasteurised milk, conducted in 2008 as part of the "National Evaluation of Milk", it was found that after 5 days of storage $13 \%$ of the analysed milk samples showed defects of taste and odour, whereas in the last day of storage defects occurred in $38 \%$ of the samples. Low sensory quality was associated with the perceptibility of cowshed, bitter, forage and unclean taste and smell. In some milk samples changes were also found in the appearance. The results of these studies indicate that stability of low-pasteurised milk does not always correspond with the shelf life declared by the manufacturers [Jakubczyk \& Bogdańska-Zaręba, 2009].

The results of microbiological tests and sensory evaluation obtained in the present study indicate the high quality of market milk. According to literature, the continuous improvement of the microbiological quality of milk is observed recently in Poland. This is due to a whole range of undertaken activities such as increasing requirements for the raw milk bought by dairy plants (according to the requirements of the European Union), increasing hygienic standards in dairy plants, and using new packaging materials for milk. The introduction of the HACCP principles in dairy plants and improvement of the system are also important [Molska \& Pałubińska, 2006; Ziarno et al., 2006]. Smigic et al. [2009] reported on the improvement in the microbiological quality of pasteurised milk eight months after HACCP implementation in a dairy plant in Serbia. The total plate count decreased from $3.11 \pm 0.30$ to $2.18 \pm 0.54 \log \mathrm{CFU} / \mathrm{mL}$. These changes resulted from additional investments covering pasteurisation unit, automated cleaning and disinfection system [Smigic et al., 2009].

Literature data indicates that heat treatment affects the sensory quality of milk. Milk subjected to the UHT pro- cess has lower sensory quality and poorer flavouring profile with noticeable cooking note when compared to pasteurised products. For consumers, flavour is one of the most significant quality attributes owing to the overall acceptability of a food product. some consumers find the flavour of UHT milk to be undesirable [Zabbia et al., 2012; Clare et al., 2005].

In the present work, in order to compare the sensory profile of market milk preserved at different temperatures, the milk samples with $2 \%$ of fat were selected for further evaluation by the profiling method. Results of this analysis (Figure 1) enable assuming that the odour profile of the tested samples was dominated by the milk odour accompanied by the sweet note smell. Significantly lower intensity of the milk odour was indicated for the milk products which were preserved by microfiltration and pasteurisation method, while higher intensity was found for milk preserved using high-temperature pasteurisation and UHT method. The tested milk subjected to microfiltration and low pasteurisation was also characterised by lower intensity of sweet and creamy odour compared to other evaluated milk samples. Significant differences in the intensity of sweet smell were perceived between sample p4 MFLP (significantly lower intensity) and products preserved with the UHT method as well as sample p4 HP. Striking differences in the intensity of creamy odour were observed between all samples of microfiltrated and pasteurised milk (p3 MFLP and p4 MFLP - significantly lower intensity) and samples of UHT milk (p9 UHT and p10 UHT). The boiled milk aroma was highly perceptible in products subjected to UHT preservation however, the significant difference was observed only

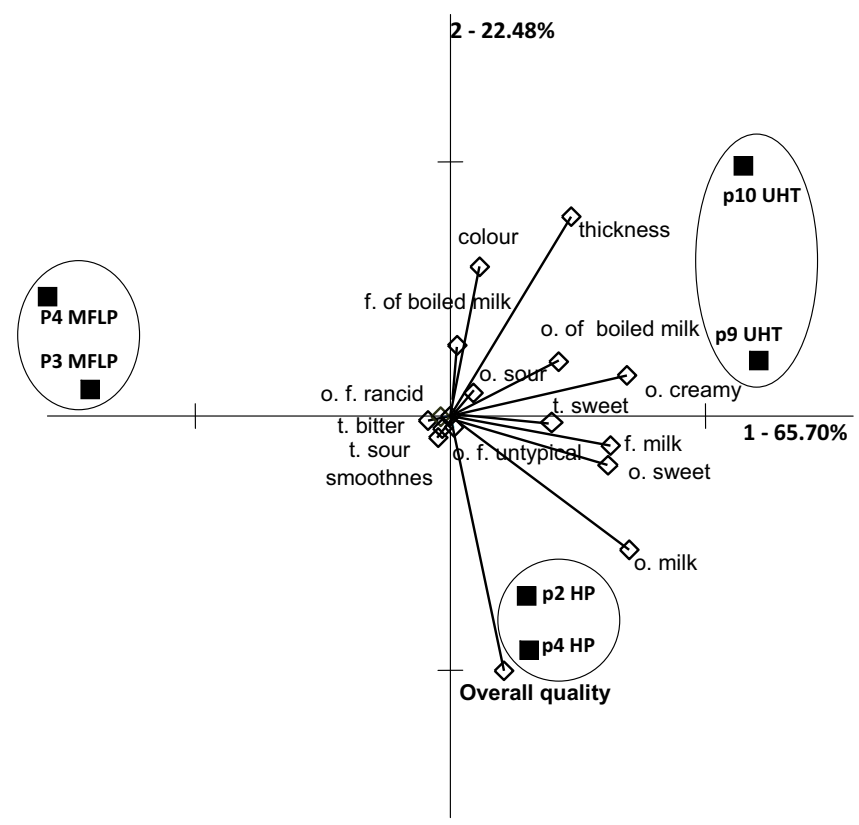

FIGURE 2. Principal Component Analysis plot of similarities and differences of sensory profiling characteristic of the milk samples containing $2 \%$ of fat, preserved with different methods.

Explanatory notes: UHT - sterilised milk; HP - milk pasteurised at high temperature; MFLP - milk subjected to microfiltration and low pasteurisation. Tested attributes: o. - odour, t. - taste; f. - flavor; o. sweet; o. milk; o. sour; o. of boiled milk; o. creamy; o. rancid; o. untypical; colour; thickness; smoothness; t. sweet; f. milk; f. of boiled milk; t. sour; t. bitter; o. rancid; f. untypical; overall quality. 
between sample p9 UHT and microfiltrated and pasteurised milk (p3 MFLP, p4 MFLP). In the examined milk, sour odour intensity was very low and did not differentiate the samples. Moreover, the rancid odour did not occur in the evaluated samples. UHT milk samples were characterised by intense colour, but these differences were not significant in comparison with the other tested samples.

All tested milk samples, irrespective of the preservation method, were characterised by high smoothness, they differed however in terms of thickness perception. The most dense was UHT milk - the significant differences, however, were found between p10 UHT sample and milk preserved by high pasteurisation (p2 HP, p4 HP) and microfiltered and pasteurised samples (p3 MFLP, p4 MFLP). The taste profile of evaluated milk, as well as odour profile, was dominated by the milk flavour, accompanied by a sweet taste note. Microfiltered and pasteurised milk had a lower intensity of milk flavour. Significant differences in the intensity of this attribute were found between $\mathrm{p} 9$ UHT and microfiltrated and pasteurised milk (p3 MFLP, p4 MFLP). The intensity of sweet taste was slightly higher in samples of UHT milk but these differences were not statistically significant. The intensity of the boiled milk's taste was similar in all evaluated milk samples. Like in the case of odour profile, the intensity of sour taste was rather low and did not differentiate the samples in taste profile. There was no presence of bitter and rancid taste - attributes that may adversely affect the sensory quality of the evaluated products.

The overall quality of evaluated milk was rated relatively high - in the range of $6.7-7.23$ points. Samples of milk pasteurised at high temperature got the highest scores of the overall quality. Especially, the overall quality of p4 HP sample was significantly higher compared to milk samples microfiltered and pasteurised ( $\mathrm{p} 3$ MFLP, p4 MFLP) and one of the UHT milk (p10 UHT). There was no difference in the overall quality between UHT milk and products preserved through microfiltration and low pasteurisation.

Figure 2 shows a map of the PCA of similarities and differences in the sensory profile of tested milk samples. The space on the map was determined by the first two components, which explains more than $88 \%$ of the variability of the tested products. The overall quality was positively correlated with the milk and sweet odour and taste. Three clusters created by the samples on the PCA map can be observed, which indicates significant similarity between products included to the same cluster. Each of the cluster includes milk samples subjected to the same heat treatment method. Samples of milk pasteurised at high temperature were located close to the overall quality vector and attributes positively correlated with it. UHT milk was located near vectors of cream and boiled milk odour and thickness, which reflects the relatively high intensity of these sensory attributes in the general profile of that milk in relation to the other tested samples. The milk samples pasteurised by low pasteurisation and microfiltration were located on the opposite side of the scheme, the lack of vector in the vicinity of the evaluated parameters may be noticed. This is due to the fact that in their aroma-taste profile the intensity of evaluated parameters was lower or very close to the other evaluated samples.
The influence of heating on milk sensory quality is supported by scientific research. UHT processing leads to the formation of cooked flavour in milk. Development of this flavour is associated with the presence of a variety of sulfur-containing compounds including inter alia hydrogen sulfide, dimethyl sulfide, dimethyl disulfide and dimethyl trisulfide (all of which have extremely low detection thresholds). The higher heat severity of UHT processing compared to pasteurisation causes a marked difference in the quantitative and qualitative composition of volatile sulfur compounds (VSCs) between UHT and pasteurised milk. A major reason for this is much greater extent of $\beta$-lactoglobulin denaturation in UHT milk. Pasteurised milk contains also several VSCs, but most of them are at sub-flavour threshold concentrations so they do not contribute to the flavour of pasteurised milk [Al-Attabi et al., 2014; Zabbia et al., 2012; Clare et al., 2005].

The reactions of VSCs formation in milk depend not only on processing temperature but also on the milk's matrix, especially fat content. The cooked flavour is more intensive in whole milk than in skinned milk, subjected to the same heat treatment. Milk fat globule membrane protein plays a significant role in VSCs development, so the concentration of VSCs in whole UHT milk is higher than in skimmed milk. Generally, as the fat percentage increases, the concentration of VSCs increases and the cooked flavour is intense [Al-Attabi et al., 2014; Vazquez-Landaverde et al., 2005].

According to literature data, cooked flavour is the most intensive directly after thermal processing and gradually disappears during storage, which corresponds to the decreased concentration of the VSCs. Cooked flavour is replaced by an off-flavour note characterised as stale. This is associated with the formation of methyl ketones via the thermal decarboxylation of $\beta$-keto acids as well as the initiation of lipid oxidation in the milk leading to an increase in the formation of aliphatic aldehydes during storage [Zabbia et al., 2012; Vazquez-Landaverde et al., 2005; Valero et al., 2001].

\section{CONCLUSIONS}

Microbiological quality of evaluated milk samples at the end of the storage period showed satisfactory microbiological purity, which proves the effectiveness of the heat treatment and absence of recontamination, as well as high-quality of raw material. All tested milk samples were characterised by high sensory quality at the end of the storage period. There were no changes in flavour and texture, indicating the development of undesirable microflora. The sensory profile of tested milk varied among samples preserved with different methods (sterilisation, pasteurisation at high temperature, microfiltration and low pasteurisation). The most harmonised overall quality was observed for milk samples preserved by high pasteurisation.

\section{ACKNOWLEDGEMENTS}

The authors address their special thanks to Krajowy Związek Spółdzielni Mleczarskich Związek Rewizyjny w Warszawie for providing research material and financial support for the research. 


\section{REFERENCES}

1. Aires G.S., Walter E.H., Junqueira V.C., Roig S.M., Faria J.A.,, Bacillus cereus in refrigerated milk submitted to different heat treatments. J. Food Prot., 2009, 72, 6, 1301-1305.

2. Al-Attabi Z., D'Arcy B.R., Deeth H.C., Volatile sulphur compounds in pasteurized and UHT milk during storage. Dairy Sci. Technol., 2014, 94, 3, 241-253.

3. Clare D.A., Bang W.S., Cartwright G., Drake M.A., Coronel P., Slmunovic J., Comparison of Sensory, Microbiological, and Biochemical Parameters of Microwave Verses Indirect UHT Fluid Skim Milk During Storage. J. Dairy Sci., 2005, 88, 4172-4182.

4. Commission Regulation (EC) No 273/2008 of 5 March 2008 laying down detailed rules for the application of Council Regulation (EC) No 1255/1999 as regards methods for the analysis and quality evaluation of milk and milk products.

5. Commission Regulation (EC) No 2073/2005 of 15 November 2005 on microbiological criteria for foodstuffs.

6. Dzwolak W., Ziajka S., Mleko i śmietanka spożywcza. W: Mleczarstwo - zagadnienia wybrane. t.. 2. Red. S. Ziajka. Wyd. ART, Olsztyn 1997, pp. 7-61 (in Polish).

7. Ebringer L., Ferencík M, Krajcovic J., Beneficial health effects of milk and fermented dairy products - review. Folia Microbiol. (Praha), 2008, 53, 5, 378-394.

8. Fromm H.I., Boor K.J., Characterization of pasteurized fluid milk shelf-life attributes. J. Food Sci., 2004, 69, 8, M207-M214.

9. Gandy A.L., Schilling M.W., Coggins P.C., White C.H., Yoon Y., Kamadia V.V., The effect of pasteurization temperature on consumer acceptability, sensory characteristics, volatile compound composition, and shelf-life of fluid milk. J. Dairy Sci., 2008, 91, 5, 1769-1777.

10. Hayes W., White C. H., Drake M. A., Sensory aroma characteristics of milk spoilage by Pseudomonas species. J. Food Sci., 2002, 67, 2, 861-867.

11. Hettinga K.A., van Valenberg H.J.F., van Hooijdonk A.C.M., Quality control of raw cows' milk by headspace analysis. Int. Dairy J., 2008, 18, 5, 506-513.

12. IDF Standard 99 C:1997, part. 1; part. 3.

13. Jakubczyk E., The quality of pasteurized milk. Przem. Spoż., 2004, 59, 3, 42- 46 (in Polish; abstract in English).

14. Jakubczyk E., Bogdańska-Zaręba H., The quality of milk. Przegl. Mlecz., 2009, 6, 8-12 (in Polish; abstract in English).

15. Karatapanis A.E., Badeka A.V., Riganakos K.A., Savvaidis I.N., Kontominas, M.G. Changes in flavour volatiles of whole pasteurized milk as affected by packaging material and storage time. Int. Dairy J., 2006, 16, 7, 750-761.

16. Molska I., Pałubińska A., Microbiological quality and durability of the pasteurized milk in Warsaw market. Przegl. Mlecz., 2006, 8, 4-7 (in Polish).

17. Molska I., Significance of bacteria from Enterobacteriaceae family in food products. Przem. Spoż., 2007, 3, 30-32 (in Polish; abstract in English).
18. PN-EN ISO 4833:2004/Ap1:2005. Microbiology of food and animal feed. Horizontal method for the enumeration of microorganisms. Plate method at $30^{\circ} \mathrm{C}$.

19. PN-EN ISO 8586:2014-03 Sensory analysis -- General guidelines for the selection, training and monitoring of selected assessors and expert sensory assessors

20. PN-EN ISO 13299:2010 Sensory Analysis. - Methodology. General guidelines for determining the sensory profile.

21. PN-EN ISO 8589:2010 Sensory Analysis. General guidelines for the design of test rooms.

22. PN-ISO 21528-2:2005. Microbiology of food and animal feed. Horizontal method for the detection and enumeration of Enterobacteriaceae Part 2: Plate method.

23. Rysstad G., Kolstad J., Extended shelf life milk - advances in technology. Int. J. Dairy Technol., 2006, 59, 2, 85-96.

24. Sakkas L. , Moutafi A., Moschopoulou E., Assessment of heat treatment of various types of milk. Food Chem., 2014, 159, 293-301.

25. Skrzypek J., Cais-Sokolińska D., Piku J., Skrzypek M., Microbiological quality of microfiltrated and pasteurized milk. Przegl. Mlecz., 2002, 5, 229-233 (in Polish; abstract in English).

26. Smigic N., Djekic I., Tomasevic I., Miocinovic J., Gvozdenovic R., Implication of food safety measures on microbiological quality of raw and pasteurized milk. Food Contr., 2012, 25, 2, 728-731.

27. Świderski F., Mleko spożywcze, śmietanka i śmietana, in: Towaroznawstwo żywności przetworzonej z elementami technologii. Red. F. Świderski i B. Waszkiewicz-Robak. Wyd. Nauk. SGGW, Warszawa 2010, pp. 171-190 (in Polish).

28. Tortorello M.L., Indicator Organisms for Safety and QualityUses and Methods for Detection: Minireview. J. AOAC Int., 2003, 86, 6, 1208-1217.

29. Valero E., Villamiel M., Miralles B., Sanz J., Martinez-Castro I., Changes in flavour and volatile components during storage of whole and skimmed UHT milk. Food Chem., 2001,72, 1, $51-58$.

30. Vazquez-Landaverde P.A., Velazquez G., Torres J.A., Qian M.C., Quantitative determination of thermally derived off-flavor compounds in milk using solid-phase microextraction and gas chromatography. J. Dairy Sci., 2005, 88, 11, 3764-3772.

31. Zabbia A., Buys E.M., De Kock H.L., Undesirable sulphur and carbonyl flavor compounds in UHT milk. Crit. Rev. Food Sci. Nutr., 2012, 52, 1, 21-30.

32. Ziarno M., Molska I., Gronczyńska M., Sobota A., The microflora of pasteurized milk. Part I. Przegl. Mlecz., 2006, 10, 10-12 (in Polish).

33. Zmarlicki S., The nutritional value of milk protein, milk fat, lactose. Przem. Spoż., 2009, 63, 11, 33-37 (in Polish; abstract in English).

Submitted: 9 May 2014. Revised: 5 September 2014. Accepted: 11 September 2014. Published on-line: 29 June 2015. 
